\title{
Effect of High Temperature on Morpho-physiological Attributes of Different Mustard (Brassica juncea (L.) Czern \& Coss) Genotypes under Late Sown Condition
}

\author{
Sanjay Kumar Tripathi*, Lallu, S. P. Kushwaha, Mayank Pratap, Madhukar Singh, \\ Vikas Yadav and Shubham Kumar Srivastava
}

\author{
Department of Crop Physiology, Chandra Shekhar Azad University of Agriculture \& \\ Technology, Kanpur-208002 (U.P.) India
}

*Corresponding author

Keywords

Plant height,

Branches, Silliqua, Mustard

Article Info

\section{Accepted:}

08 January 2020

Available Online:

10 February 2020

\section{A B S T R A C T}

The present investigation entitled "Effect of High Temperature on Morpho-Physiological Attributes of Different Mustard (Brassica juncea L. Czern \& Coss) Genotypes Under Late Sown Condition" was conducted in Randomized Block Design (RBD) with 12 new promising mustard genotypes viz., (Vardan, Ashirwad, NPJ-207, NPJ-208, RGN-403, PBR-417, DRMRIJ 16-3, DRMR-2035, RRN-911, RH-1556, RGN-368 and BPR 541-4) widely differing in their physiological maturity in two consecutive years (2017-18 and 2018-19) to envisage genotypic variability for morphological, physiological, yield, its attributes and correlation coefficient under late sown condition. Results revealed that almost all traits varied significantly due to genotypes during both years of study under late sown conditions. Findings disclosed that mustard genotypes viz., DRMRIJ 16-3, RGN403, and RH-1556 recorded higher value of Plan height $(\mathrm{cm})$, branches plant ${ }^{-1}$ i.e., primary, Secondary and tertiary branches and number of siliqua in different branches. Results also showed that, these traits possessed significantly positive correlation-ship with grain yield thereby indicates their involvement in process of heat tolerance mechanism under late sown conditions. These traits which are simple in measurement can be used as an index for assessing terminal heat tolerance in mustard genotypes under late sown condition. Based on overall relative performance it was concluded that mustard genotypes viz., DRMRIJ 16-3, RGN-403, RH-1556 and NPJ-208 were found to perform better with respect of seed yield and its other components as compared to other genotypes thereby proved to be more tolerant to terminal heat stress under late sown conditions.

\section{Introduction}

Indian mustard [Brassica juncea (L.) czernj \& coss ] is known as Rai, Raya or Laha which is belonging to the family Brassicaceae. Mustard [Brassica juncea (L.) Czern \& Coss] is an important Rabi season oilseed crop which belongs to family crucifereae (Brassicaceae) and genus Brassica. Indian mustard or brown mustard is natural amphidiploids having chromosome no. $(2 n=36)$ with its origin place is China. It is 
self- pollinated crop but certain amount (2$15 \%)$ of cross pollination occurs due to insects and other factors. It is considered to be the most productive amongst all the brassicas cultivated in India which covers alone largest area $(85-90 \%)$ in the country and most popular among farmers of whole country. Indian mustard has very good oil quality. It is now a well known fact that mustard oil is nutritionally superior to other edible oils due to appreciable amount of omega 3 and omega 6 fatty acids in desired proportion (Mangla Rai 2006). The oil is utilized for human consumption throughout northern India in cooking and frying purposes. The oil cake is used as a cattle feed and manure. Green stems and leaves are a good source of green fodder of cattle. The leaves of young plants are used as green vegetables as they supply enough sulphur and minerals in the diet.

Oilseed crop play an important role in agriculture economy of India. Our country is the largest oil economy in the world after the U.S., China and Brazil in term of vegetable oil. India occupies the second position in area after China and third position in production in the world after China and Canada. In India, during year 2016-2017, the area of Rapeseedmustard was 68.17 lakh ha. with the production of 75.62 lakh $\mathrm{mt}$. and productivity of 12.01 quintal/ha. In U.P during the year 2016-2017 the area of rapeseed-mustard was 9.86 lakh ha. with the production of 12.56 lakh mt. and productivity of 14.95 quintal/ha (Anonymous,2016-17). Currently, India accounts for about $12-13 \%$ of world oilseeds area, $6-7 \%$ of world vegetable oil production, $15-17 \%$ of world vegetable oil import and $10 \%$ of the world edible oil consumption. With the diverse agro-ecological conditions prevailed, nine different oilseed crops are grown in India which include seven edible, viz. Groundnut, mustard, Rapeseed, Soybean, Sunflower, Sesame and Niger and two nonedible sources, viz., castor and linseed.
Among different oilseed groundnut, rapeseedmustard and soybean account for nearly $77 \%$ of total oilseed production in the country.

Indian mustard is sown late due to delay in harvesting of rainy season crops like cluster bean, cotton and rice (Kumar et al., 2013). Under late sown condition, productivity declines primarily due to the shortening of vegetative and reproductive phase. Late sown Indian mustard is exposed to high temperature coupled with high evaporative demand of the atmosphere, during the reproductive phase which consequently results in forced maturity, increased senescence and low productivity (Porter, 2005). The rise in temperature, even by a single degree beyond the threshold level is considered as heat stress in the plants (Hasanuzzaman et al., 2013, Wahid et al., 2007). The global mean surface air temperature increased by $0.5^{\circ} \mathrm{C}$ in the twentieth century and is expected to increase a further $1.5-4.5^{\circ} \mathrm{C}$ by the late twenty-first century (IPCC, 2012). Climate change has increased the intensity of heat stress and heat stress due to increased temperature is an agricultural problem in many areas in the world as well as in India.

\section{Materials and Methods}

The field experiment was conducted at Oil seed research Farm Kalyanpur, of C. S. Azad University of Agriculture and Technology, Kanpur, Uttar Pradesh. This farm is situated about $3 \mathrm{~km}$ away from main campus of university on South side of G.T. road runs towards Delhi. Experimental field was well leveled and had assured irrigation facilities. The experimental place Kanpur is situated at latitude of $26^{\circ} 28^{-}$North and longitude of $80^{\circ}$ 24`East.

The altitude is about $129 \mathrm{~m}$ above mean sea level. It has semi-subtropical climate. The average annual rainfall of the region is 762 
$\mathrm{mm}$ and most of it is received since last week of June to middle of October month.

The soil is built from Gangetic alluvium. To know the important characteristics of experimental soil; the samples were drawn at the depth of $0-30 \mathrm{~cm}$ from different places in experimental area randomly before sowing and application of fertilizers but after the land preparation.

The results of soil analysis indicated that experimental soil was sandy loam in texture and slightly alkaline in nature. It was low in organic carbon, available nitrogen, available $\mathrm{P}_{2} \mathrm{O}_{5}$ but medium in available $\mathrm{K}_{2} \mathrm{O}$ content. Soil moisture content in soil at sowing time of crop was sufficient for proper germination of crop seeds.

\section{Plant height (cm)}

Plant height was measured with the help of meter scale and recorded at pre flowering, flowering and post flowering and at harvest in three tagged plants in each plot. The height was measured from the base of the plant to the tip of the main stem of randomly tagged plants and mean values were calculated.

\section{Branches per plant (Nos)}

The number of primary, secondary and tertiary branches per plant counted separately after then total number of branches per plants was noted.

\section{Siliquae on different branches and plant $^{-1}$ (Nos)}

Number of siliquae on different branches of each of the randomly five selected plants in each treatment per replication were counted separately at maturity and expressed on per plant basis as mean number of siliquae on different branches.

\section{Results and Discussion}

\section{Plant height (cm)}

Plant height of different evaluated mustard genotypes was measured at pre flowering, flowering, post flowering and at harvest and the data obtained are presented in Table-1. At pre-flowering genotypes RGN-403 $(24.0 \mathrm{~cm})$, being at par with PBR-417 $(23.3 \mathrm{~cm})$ and in RRN-911 $(22.7 \mathrm{~cm})$ in the first year while in second year RH-1556 (24.2 cm), statistically at par with Vardan $(24.0 \mathrm{~cm}), \mathrm{RGN}-403$ (23.0 $\mathrm{cm})$ and PBR-417 (22.9 cm) recorded significantly higher value of it as compared to other genotypes under late sowing stress. On the other hand significantly lowest plant height was noted in DRMR-2035 $(17.6 \mathrm{~cm})$ and Ashirwad $(17.8 \mathrm{~cm})$ in first year and RGN-368 $(18.6 \mathrm{~cm})$ followed by DRMR$2035(18.8 \mathrm{~cm})$ in second year. Rest mustard genotypes showed plant height in between $(19.7$ to $24.0 \mathrm{~cm})$ in the first year and from 20.1 to $22.2 \mathrm{~cm}$ in the second year. At flowering stage significantly higher value of plant height was recorded in genotypes RH$1556(78.3 \mathrm{~cm})$ being at par with Ashirwad $(75.6 \mathrm{~cm})$ in the first year and in second year it was recorded significantly higher in DRMRIJ 16-3 $(76.5 \mathrm{~cm})$ being at par with Vardan $(74.3 \mathrm{~cm})$, BPR $541-4(74.2 \mathrm{~cm})$ and RGN-403 $(73.3 \mathrm{~cm})$. On contrary of this significantly lowest value was recorded in BPR 541-4 $(59.3 \mathrm{~cm})$ followed by RGN-368 in first year and in second year genotype RGN-368, PBR-417 (59.3 cm) and RRN-911 $(59.5 \mathrm{~cm})$ showed lowest plant height under late sowing. In rest of the mustard genotypes plant height remained in between 62.2 to 73.1 $\mathrm{cm}$ and 64.4 to $70.3 \mathrm{~cm}$ respectively in first and second year of study. At post-flowering stages genotypes RH-1556 $(137.3 \mathrm{~cm})$ being at par with Vardan $(134.5 \mathrm{~cm})$ and DRMRIJ $16-3(131.6 \mathrm{~cm})$ had relatively higher value of plant height in 2017-18 and RGN-403 (139.6 $\mathrm{cm})$ followed by Vardan $(133.0 \mathrm{~cm})$ noted 
higher in 2018-19 while the lowest value of it was recorded in RGN-368 (107.4, $106.9 \mathrm{~cm})$ and RRN-911 (109.1, $109.3 \mathrm{~cm})$ during both years of study under late sown condition. Rest recorded plant height in between 113.0 to $123.2 \mathrm{~cm}$ and 110.4 to $125.6 \mathrm{~cm}$ in $2017-18$ and 2018-19 respectively. At harvest stage genotype RH-1556 (166.1 cm) recorded significantly maximum plant height followed by DRMRIJ $16-3(165.2 \mathrm{~cm})$ in the first year while in second year it occurred higher in RGN-403 (168.6 cm) followed by DRMRIJ 16-3 (164.1 cm) as compared to other genotypes against the lowest value of plant height was noted in PBR-417 $(126.2 \mathrm{~cm})$ and Ashirwad $(127.0 \mathrm{~cm})$ in first year and in RRN-911 (127.2 cm) and BPR 541-4 (133.0 $\mathrm{cm})$ in second year.

Rest grown genotypes had plant height in between 134.3 to $154.7 \mathrm{~cm}$ in first year and from 135.7 to $153.6 \mathrm{~cm}$ in second year. Based on pooled analysis mustard genotype RGN403 recorded highest plant height at preflowering, Vardan at both flowering and postflowering, DRMRIJ 16-3 at harvest under late sown condition while the minimum plant height recorded with mustard genotype DRMR-2035 at pre-flowering RGN-368 both at flowering and post flowering and PBR-417 at harvest stage under late sown situation. The reduction in plant height during delay sowing might be due to reduction in duration of vegetative growth stage, which slows the cell expansion and their growth (Meena et al., 2015). Similar observation earlier recorded by Kumari et al., (2012) under late sowing. Singh et al., (2014) also found that 26 November sown crop of Indian mustard caused $22.8 \%$ reduction in plant height due to high temperature stress probably related to decline in photosynthetic products. Similar results were also reported by Patel et al., (2017), Pattam et al., (2017) and Singh et al., (2017). From the results it appear that plant height is inherent characters of genotypes which influenced by prevailing environment under late sown condition.

\section{Number of branches per plant at harvest}

Numbers of primary, secondary and tertiary branches per plant were recorded at harvest and the data so obtained are presented in Table-2. Number of primary branches per plant were recorded significantly maximum in mustard genotype DRMRIJ 16-3 (7.8, 7.1) being at par with RGN-403 $(7.4,6.5)$ during both first year and in second year respectively. On contrary of this, significantly minimum values of these branches were counted in RRN-911 (3.9, 4.5) and RGN$368(4.5,4.5)$ in during both years. The data so obtained revealed that mustard genotype DRMRIJ16-3 (12.0), being at par with RGN403 (11.0) had relatively higher number of secondary branches in first year and in second year genotypes RH-1556 (12.0) followed by RGN-403 (11.4) gave higher number of secondary branches. On the other hand significantly minimum numbers of these branches were recorded in genotype RRN-911 (7.9) and Ashirwad (7.9) respectively during 2017-18 and 2018-2019. Numbers of tertiary branches per plant were concerned, these also varied significantly among the promising mustard genotypes tried in this study. In this regard genotypes DRMRIJ 16-3, NPJ-208 (5.6) and NPJ-207 (5.4) had relatively higher number of tertiary branches per plant during first year and in second year genotypes NPJ(208), RGN-403, DRMR-2035 (5.3) and DRMRIJ 16-3 (5.1) had relatively higher number of tertiary branches per plant as compared to other genotypes under late sowing. Minimum numbers of these branches were observed in genotype RRN-911 and Vardan (3.9) during the first year and in second year genotype RGN-368 (3.7) also gave lowest value of these under late sowing. Numbers of primary, secondary, tertiary and total branches per plant were counted at 
harvest stage. Based on pooled analysis DRMRIJ 16-3 followed by RGN-403 and RH-1556 produced maximum primary branches as well as total branches per plant, whereas genotypes RRN-911 and RGN-368 not responds better and produced lowest number of primary and total branches per plant under late sowing stress. The remaining genotypes under the grown situation bears primary and total branches per plant in between minimum and maximum mentioned above. These results were somewhat in accordance with the findings of Pradhan et al., (1997). Among the evaluated genotypes RH-1556 followed by DRMRIJ 16-3 and RGN-403 produced significantly higher number (> 11.0) of secondary branches per plant as compared to other genotypes whereas, NPJ-208 followed by DRMRIJ 16-3, DRMR-2035 and NPJ-207 produced higher number of tertiary branches per plant $(>5.0)$ over the other under late sowing environment on pooled basis.

Under late sown stress Ashirwad and BPR 541-4 in respect of secondary branches per plant and RRN-911 and RGN-368 in respect of tertiary branches per plant did not perform better and produced least number of these branches per plant as compared to other genotypes. Number of branches per plant produced in different tested genotypes seems to maintain their inherent characteristics for branching behavior against high temperature under late sowing. Similar results of varietal differences in branching behavior in mustard have been reported by Lallu and Dixit (2008), Lallu et al., (2010), Sharma and Shardana (2014).

\section{Number of siliquae on different branches per plant at harvest}

Data with respect to number of siliquae produced by different branches and also their total per plant are presented in Table-3.
Number of siliquae produced on main shoot within the genotypes varied from 24.4 to 30.6 in the first year, and from 24.7 to 32.0 in the second year Table-3. Significantly maximum number of siliquae were noted in genotype DRMRIJ 16-3 (30.6, 32.0) being statistically at par with RGN-403 (30.1. 30.4) and RH1556 (29.1, 29.2) during both years while Vardan (28.7) and NPJ-208 (28.4) only in first year under late sowing stress as compared to other genotypes. On contrary of this the minimum values of these were noted during both first and second years in RRN911 (24.4, 24.7) and in RGN-368 (25.0, 25.1) respectively under late sowing.

Remaining genotypes of mustard on the main branch produced number of siliquae in the range of 25.3 to 28.7 and 25.3 to 28.8 in 2017-18 and 2018-19 respectively under late sowing stress. Genotypes DRMRIJ 16-3, RGN-403 and RH-1556 proved as superior as these gave significantly higher value of siliquae on main shoot based on pooled analysis of both years over the other genotypes tested.

Number of siliquae born on primary branches of mustard genotypes RGN-403 (145.0, 145.5), RH-1556 (143.9, 143.2) DRMRIJ 163 (143.5, 143.7) and Vardan ( 141.8, 142.3) during first year and in second year respectively were at par and significantly higher than other genotypes sown under late sowing. On the other hand significantly minimum values of these were noted in RRN911 (134.2, 133.9), followed by RGN-368 (135.0, 135.6) and BPR 541-4 (135.0, 135.5) during both first and second year respectively under late sown situation.

Remaining genotypes of mustard produced siliquae on their branches were recorded in the range of 136.5 to 141.8 and 135.6 to 142.3 in 2017-18 and 2018-19 respectively. 
Table.1 Plant height $(\mathrm{cm})$ at different growth stages

\begin{tabular}{|c|c|c|c|c|c|c|c|c|c|c|c|c|}
\hline \multirow{2}{*}{$\begin{array}{c}\text { Year } \\
\text { Genotypes }\end{array}$} & \multicolumn{4}{|c|}{ 2017-18 } & \multicolumn{4}{|c|}{ 2018-19 } & \multicolumn{4}{|c|}{ Pooled } \\
\hline & $\begin{array}{c}\text { Pre- } \\
\text { flowering }\end{array}$ & Flowering & $\begin{array}{c}\text { Post- } \\
\text { flowering }\end{array}$ & harvest & $\begin{array}{c}\text { Pre - } \\
\text { flowering }\end{array}$ & Flowering & $\begin{array}{c}\text { Post- } \\
\text { flowering }\end{array}$ & harvest & $\begin{array}{c}\text { Pre- } \\
\text { flowering }\end{array}$ & $\begin{array}{c}\text { Floweri } \\
\text { ng }\end{array}$ & $\begin{array}{c}\text { Post- } \\
\text { flowering }\end{array}$ & Harvest \\
\hline Vardan & 19.7 & 73.1 & 134.5 & 143.3 & 24.0 & 74.3 & 133.0 & 145.8 & 21.9 & 73.7 & 133.8 & 144.6 \\
\hline Ashirwad & 17.8 & 75.6 & 121.6 & 127.0 & 22.2 & 70.3 & 125.6 & 148.9 & 20.0 & 73.0 & 123.6 & 138.0 \\
\hline NPJ-207 & 19.8 & 69.4 & 122.3 & 139.2 & 21.1 & 68.2 & 122.0 & 140.7 & 20.5 & 68.8 & 122.2 & 140.0 \\
\hline NPJ-208 & 22.5 & 63.8 & 116.3 & 154.7 & 20.3 & 65.4 & 114.3 & 153.6 & 21.4 & 67.4 & 115.3 & 154.2 \\
\hline RGN-403 & 24.0 & 71.2 & 123.2 & 150.6 & 23.0 & 73.3 & 139.6 & 168.6 & 23.5 & 72.3 & 131.4 & 159.6 \\
\hline PBR-417 & 23.3 & 68.3 & 115.6 & 126.2 & 22.9 & 59.3 & 110.4 & 135.7 & 23.1 & 63.8 & 113.0 & 131.0 \\
\hline $\begin{array}{l}\text { DRMRIJ } \\
16-3\end{array}$ & 21.4 & 70.3 & 131.6 & 165.2 & 21.0 & 76.5 & 120.3 & 164.1 & 21.2 & 73.4 & 126.0 & 164.7 \\
\hline $\begin{array}{l}\text { DRMR- } \\
2035\end{array}$ & 17.6 & 68.0 & 118.2 & 146.4 & 18.8 & 64.4 & 121.0 & 145.1 & 18.2 & 66.2 & 119.6 & 145.8 \\
\hline RRN-911 & 22.7 & 62.2 & 109.1 & 138.3 & 20.1 & 59.5 & 109.3 & 127.2 & 21.4 & 60.9 & 109.2 & 132.8 \\
\hline RH-1556 & 21.1 & 78.3 & 137.3 & 166.1 & 24.2 & 68.2 & 120.3 & 152.8 & 22.7 & 73.3 & 128.8 & 159.5 \\
\hline RGN-368 & 20.5 & 61.5 & 107.4 & 134.3 & 18.6 & 59.3 & 106.9 & 135.7 & 19.6 & 60.4 & 107.2 & 135.0 \\
\hline BPR 541-4 & 21.1 & 59.3 & 113.0 & 147.1 & 22.9 & 74.2 & 118.0 & 133.0 & 22.0 & 66.8 & 115.5 & 140.1 \\
\hline Mean & 21.0 & 68.4 & 120.8 & 144.8 & 21.6 & 67.7 & 120.0 & 145.9 & 21.3 & 68.4 & 120.5 & 145.4 \\
\hline SE(d) & 0.82 & 1.74 & 4.56 & 5.38 & 0.89 & 2.10 & 5.24 & 6.43 & 0.59 & 1.34 & 3.40 & 4.10 \\
\hline C.D. & 1.69 & 3.61 & 9.45 & 11.17 & 1.85 & 4.36 & 10.89 & 13.34 & 1.19 & 2.69 & 6.85 & 8.26 \\
\hline
\end{tabular}


Table.2 Number of primary, Secondary and tertiary branches per plant at harvest

\begin{tabular}{|c|c|c|c|c|c|c|c|c|c|c|c|c|}
\hline \multirow{2}{*}{$\begin{array}{c}\text { Year } \\
\text { Genotypes }\end{array}$} & \multicolumn{4}{|c|}{ 2017-18 } & \multicolumn{4}{|c|}{ 2018-19 } & \multicolumn{4}{|c|}{ Pooled } \\
\hline & Primary & Secondary & Tertiary & Total & Primary & Secondary & Tertiary & Total & Primary & Secondary & Tertiary & Total \\
\hline Vardan & 5.6 & 10.5 & 3.9 & 20.0 & 6.2 & 8.9 & 4.5 & 19.6 & 5.9 & 9.7 & 4.2 & 19.8 \\
\hline Ashirwad & 5.4 & 8.1 & 4.3 & 17.8 & 4.9 & 7.9 & 4.6 & 17.4 & 5.2 & 8.0 & 4.5 & 17.6 \\
\hline NPJ-207 & 5.6 & 8.6 & 5.4 & 19.6 & 4.9 & 8.8 & 5.0 & 18.7 & 5.3 & 8.7 & 5.2 & 19.2 \\
\hline NPJ-208 & 6.4 & 9.2 & 5.6 & 21.2 & 5.7 & 10.7 & 5.3 & 21.7 & 6.1 & 10.0 & 5.5 & 21.5 \\
\hline RGN-403 & 7.4 & 11.0 & 5.0 & 23.4 & 6.5 & 11.4 & 5.3 & 23.2 & 6.8 & 11.2 & 5.1 & 23.3 \\
\hline PBR-417 & 4.3 & 8.6 & 5.0 & 17.9 & 4.6 & 9.0 & 4.5 & 18.1 & 4.5 & 8.8 & 4.8 & 18.0 \\
\hline DRMRIJ 16-3 & 7.8 & 12.0 & 5.6 & 25.4 & 7.1 & 11.0 & 5.1 & 23.2 & 7.5 & 11.5 & 5.4 & 24.3 \\
\hline DRMR-2035 & 5.4 & 9.0 & 5.0 & 19.4 & 6.0 & 8.9 & 5.3 & 20.2 & 5.7 & 9.0 & 5.2 & 19.8 \\
\hline RRN-911 & 3.9 & 7.9 & 3.9 & 15.7 & 4.5 & 8.8 & 4.1 & 17.4 & 4.2 & 8.4 & 4.0 & 16.6 \\
\hline RH-1556 & 6.5 & 10.8 & 4.2 & 21.5 & 6.1 & 12.4 & 4.9 & 23.4 & 6.3 & 11.6 & 4.6 & 22.5 \\
\hline RGN-368 & 4.5 & 8.2 & 4.0 & 16.7 & 4.5 & 9.0 & 3.7 & 17.2 & 4.5 & 8.6 & 3.9 & 17.0 \\
\hline BPR 541-4 & 4.7 & 8.1 & 4.5 & 17.3 & 4.8 & 8.1 & 4.5 & 17.4 & 4.7 & 8.1 & 4.5 & 17.3 \\
\hline Mean & 5.6 & 9.4 & 4.7 & 19.6 & 5.5 & 9.6 & 4.7 & 19.8 & 5.6 & 9.5 & 4.7 & 19.7 \\
\hline $\operatorname{SE}(d)$ & 0.58 & 0.70 & 0.37 & 0.91 & 0.63 & 0.62 & 0.46 & 1.05 & 0.42 & 0.46 & 0.29 & 0.68 \\
\hline C.D. & 1.20 & 1.47 & 0.79 & 0.91 & 1.32 & 1.28 & 0.95 & 1.05 & 0.85 & 0.93 & 0.59 & 1.38 \\
\hline
\end{tabular}


Table.3 Siliquae on different Branches per plant at harvest

\begin{tabular}{|c|c|c|c|c|c|c|c|c|c|c|c|c|}
\hline \multirow{2}{*}{$\begin{array}{c}\text { Year } \\
\text { Genotypes }\end{array}$} & \multicolumn{4}{|c|}{ 2017-18 } & \multicolumn{4}{|c|}{ 2018-19 } & \multicolumn{4}{|c|}{ Pooled } \\
\hline & Main & Primary & $\mathbf{S}+\mathbf{T}$ & Total & Main & Primary & $\mathbf{S}+\mathbf{T}$ & Total & Main & Primary & $\mathbf{S}+\mathbf{T}$ & Total \\
\hline Vardan & 28.7 & 141.8 & 281.7 & 452.2 & 28.8 & 142.3 & 282.8 & 453.9 & 28.7 & 142.0 & 282.2 & 453.0 \\
\hline Ashirwad & 26.9 & 138.9 & 280.2 & 446.0 & 28.3 & 136.1 & 280.7 & 445.1 & 27.6 & 137.5 & 280.4 & 445.5 \\
\hline NPJ-207 & 27.3 & 136.7 & 281.2 & 445.2 & 27.5 & 139.5 & 281.6 & 448.6 & 27.4 & 138.1 & 281.4 & 446.9 \\
\hline NPJ-208 & 28.4 & 139.7 & 282.0 & 450.1 & 28.2 & 140.2 & 282.5 & 450.9 & 28.3 & 139.9 & 282.2 & 450.5 \\
\hline RGN-403 & 30.1 & 145.0 & 284.2 & 459.3 & 30.4 & 145.5 & 284.5 & 460.4 & 30.2 & 145.2 & 284.3 & 459.8 \\
\hline PBR-417 & 25.3 & 136.5 & 279.6 & 441.4 & 25.3 & 136.7 & 269.5 & 431.5 & 25.3 & 136.6 & 274.5 & 436.4 \\
\hline DRMRIJ 16-3 & 30.6 & 143.5 & 285.7 & 459.8 & 32.0 & 143.7 & 286.7 & 462.4 & 31.3 & 143.6 & 286.2 & 461.1 \\
\hline DRMR-2035 & 28.1 & 138.9 & 279.9 & 446.9 & 27.9 & 139.6 & 280.2 & 447.7 & 28.0 & 139.2 & 280.0 & 447.3 \\
\hline RRN-911 & 24.4 & 134.2 & 275.9 & 434.5 & 24.7 & 133.9 & 276.4 & 435.0 & 24.5 & 134.0 & 276.1 & 434.7 \\
\hline RH-1556 & 29.1 & 143.9 & 282.7 & 455.7 & 29.2 & 143.2 & 282.2 & 454.6 & 29.0 & 143.5 & 282.4 & 455.1 \\
\hline RGN-368 & 25.0 & 135.0 & 275.4 & 435.4 & 25.1 & 135.6 & 276.1 & 436.8 & 25.0 & 135.3 & 275.7 & 436.1 \\
\hline BPR 541-4 & 26.1 & 135.0 & 278.2 & 439.3 & 26.2 & 135.3 & 278.6 & 440.1 & 26.0 & 135.1 & 278.4 & 439.7 \\
\hline Mean & 27.5 & 139.1 & 280.6 & 447.2 & 27.8 & 139.3 & 280.1 & 447.3 & 27.7 & 139.2 & 280.3 & 447.2 \\
\hline $\mathrm{SE}(\mathrm{d})$ & 1.14 & 2.13 & 2.79 & 5.02 & 1.49 & 2.57 & 3.29 & 5.68 & 0.92 & 1.64 & 2.10 & 3.71 \\
\hline C.D. & 2.37 & 4.42 & 5.78 & 10.42 & 3.09 & 5.34 & 6.82 & 11.80 & 1.85 & 3.30 & 4.24 & 7.47 \\
\hline
\end{tabular}


In general, secondary and tertiary branches produced more number of siliquae than main shoot and primary branches in all genotypes of mustard under late sowing Table 4.27.

Significantly higher number of siliquae borne on these branches were recorded in DRMRIJ 16-3 (285.7, 286.7) followed by RGN-403 (284.2, 284.5) and RH-1556 (282.7, 282.2) respectively during both years of study as compared to other genotypes while significantly minimum number of these were noted in RGN-368 (275.4) and RRN911(275.9) in 2017-18 and in PBR-417 (269.4) and RGN-368 (276.1) during 2018-19 under late sowing stress. Remaining mustard genotypes produced number of siliquae on these branches remain in the range of 278.2 to 282.0 and 276.4 to 282.8 , respectively in 2017-18 and 2018-19.

Number of siliquae per plant showed significant differences varied from 434.5 to 459.8 in the first year and from 431.5 to 462.4 in the second year among 12 mustard genotypes grown under late sown condition. Among different mustard genotype DRMRIJ 16-3 $(459.8,462.4)$ being statistically at par with RGN-403 (459.3, 460.4), RH-1556 (455.7, 454.6) Vardan (452.2, 453.9) and NPJ-208 (450.1, 450.9) during both year of study produced significantly maximum number of siliquae per plant compared to other genotypes. On contrary RRN-911 (434.5) and RGN-368 (435.4) in 2017-18 and PBR-417 (431.5) and RRN-911 (435.0) in 2018-19 produced minimum number of siliquae per plant. Number of siliquae per plant were recorded in the range of 439.3 to 452.2 and 436.8 to 453.9 during 2017-18 and 2018-19 respectively in the remaining mustard genotypes tested in the late sown stress condition.

Based on pooled analysis revealed that on primary branches maximum number of siliquae were pegged in RGN-403 followed by DRMRIJ 16-3 and RH-1556 while the lower values of these were recorded in RRN911 and BPR 541-4 as compared to other genotypes. Genotypes DRMRIJ 16-3 followed by RGN-403, RH-1556 and Vardan produced maximum number of siliquae on main branch as well as on secondary + tertiary branches and also total number of siliquae per plant under late sown condition over the other genotypes. RRN-911 and RGN-368 not responded well as both adhered with significantly lowest number of siliquae on main and total per plant as compared to other tested genotypes. Genotypes PBR-417 and RGN-368 produced significantly minimum number of siliquae on secondary and tertiary branches per plant under late sown condition. Remaining genotypes produced siliquae on different branches were in the range between lower and higher recorded in above named genotypes. Hall (1992) observed that flowering is the most sensitive stage for temperature stress damage probably due to vulnerability during pollen development anthesis and fertilization leading to reduce crop yield. Genotypes with higher number of siliquae per plant in the present study may be these maintained their inherent potential to protect temperature stress damage for flowering resulted flower abortion against rising temperature under late sowing stress. These results corroborate the findings of Angadi et al., (2000); Shiwani and Kumar (2002); Sardana et al., (2008) and Dawar et al., (2018).

\section{References}

Angadi, S.V., Cutforth, H.W., Miller, P.R., Mc Conkey, B.G., Entz, M.H., Brandt, S.A., Volkmar, K.M. (2000). Response of three Brassica species to high temperature stress during reproductive growth. Canadian J. of plant Sci., 80 (4): 693-701. 
Dawar; Sandeep; Kumar, Navin and Mishra, S.P. (2018). Genetic Variability, Correlation and Path Coefficient Analysis in the Indian Mustard (Brassica juncea L. Czern and Coss) Varieties Grown in Chitrakoot, India Int.J.Curr.Microbiol.App.Sci., $\quad 7(3)$ : 883-890.

Hall, A.E. (1992). Breeding for heat tolerance. Plant Breeding Rev., 10: 129168.

Hasanuzzaman, M.; Nahar, K.; Alam, M.M.; Roychowdhury, R. and Fujita, M. (2013). Physiological, biochemical, and molecular mechanisms of heat stress tolerance in plants. International Journal of Molecular Sciences 14: 9643-9684.

Kumar, S.; Sairam, R.K. and Prabhu, K.V. (2013). Physiological traits for high temperature stress tolerance in Brassica juncea. Indian Journal of Plant Physiology, 18: 89-93.

Kumari, A.; Singh, R.P.; Yespal. (2012). Productivity, nutrient uptake and economics of mustard hybrid (Brassica juncea L.) under different planting time and row spacing. Indian Journal of Agronomy, 57(1): 61-67.

Lallu and Dixit, R.K. (2008). High temperature effect at terminal stage in mustard genotypes. Indian J. Plant physiol., 13 (2):151-158.

Lallu, Baghel, R. and Srivatava, S.B.L. (2010). Assessment of Mustard genotypes for thermo-tolerance at seed development stage. Indian $J$. of Plant physiol., 15(1): 36-43.

Meena, R.K.; Parihar, S.S.; Singh, M. and Vhanna, M. (2015). Influence of date of sowing and irrigation regimes on crop growth and yield of wheat (Triticum aestivum) band its relationship with temperature in semi arid region. Indian J. Agron., 60: 92-98.

Patel, Avinash.; Singh, A.K.; Singh,
Shivendra; Sharma, Alekh; Raghuvanshi, Nikhil. and Singh, A. K. (2017). Effect of different sowing dates on growth yield and quality of various Indian mustard (Brassica juncea L.) varieties. Int. J.Curr.Microbiol.App.Sci., 4: 71-77.

Pattam, Keerthi; Pannu, R.K.; Dhaka, A.K. and Sharma, K.D. (2017). Effect of Dates of Sowing and Nitrogen Levels on Growth and Yield of Indian mustard. Int.J.Curr.Microbiol.App.Sci., $\quad$ 6(9): 127-135.

Porter, J.R. (2005). Rising temperatures are likely to reduce crop yields. Nature, 436: 174.

Pradhan, A.C.; Ghosh, D.C. and Sarkar, S.K. (1997). Effect of late sowing time and management on growth and yield of rapeseed at teral region of west Bengal. Indian Agr., 41(2): 123-129.

Rai, M. (2006). Inaugral address, XIII annual Group meeting of AICRP (RM) at CCS HAU, Hisar on August 2, 2006.

Sardana, V.; Sangha, M.K.; Atwal, A.K. and Sheoran, P. (2008). Influence of sowing date on thermal requirements, productivity and oil quality of Indian mustard [Brassica juncea (L.) Czern \& Coss.) cultivars. J. Oilseed res., 25: 8284.

Sharma, Pushp and Sardana, Virender (2014). Screening of Indian mustard (Brassica juncea) for thermo tolerance at seedling and terminal stages. Journal of Oilseed Brassica, 4(2): 61-67.

Shivani and Kumar, Sanjeev (2002). Response of Indian mustard (Brassica juncea L.) to sowing date and row spacing in mid hills of Sikkim under rainfed conditions. Ind. J. Agron., 47(3): 405-410.

Singh, Baldeep; Thakral, N.K.; Munjal, Renu and Boken, Geeta (2017). Combining Ability Analysis: Physiological Traits for High Temperature Stress Tolerance 
in Indian mustard [Brassica juncea (L.) Czern \& Coss.]. Int. J. Pure App. Biosci., 5(5): 725-735.

Singh, M.; Rathore, S.S. and Raja, P. (2014). Physiological and stress studies of different rapeseed mustard genotypes under terminal heat stress. International Journal of Genetic Engineering and Biotechnology, 5(2): 133-142.

USDA. (2017). World agricultural production. Washington, DC, USA: United States Department of Agriculture Foreign Agricultural Service.

Wahid, A. and Close, T.J. (2007). Expression of dehydrins under heat stress and their relationship with water relations of sugarcane leaves. Biologia Plantarum, 51: 104-109.

\section{How to cite this article:}

Sanjay Kumar Tripathi, Lallu, S. P. Kushwaha, Mayank Pratap, Madhukar Singh, Vikas Yadav and Shubham Kumar Srivastava. 2020. Effect of High Temperature on Morpho-physiological Attributes of Different Mustard (Brassica juncea (L.) Czern \& Coss) Genotypes under Late Sown Condition. Int.J.Curr.Microbiol.App.Sci. 9(02): 826-836.

doi: https://doi.org/10.20546/ijcmas.2020.902.100 